\title{
Progesterone Receptor
}

National Cancer Institute

\section{Source}

National Cancer Institute. Progesterone Receptor. NCI Thesaurus. Code C17075.

Progesterone receptor (933 aa, $\sim 99 \mathrm{kDa}$ ) is encoded by the human PGR gene. This protein is involved in the regulation of transcription. 